\title{
Interplay Between SNX27 and DAG Metabolism in the Control of Trafficking and Signaling at the IS
}

\author{
Natalia González-Mancha@ and Isabel Mérida * \\ Department of Immunology and Oncology, Centro Nacional de Biotecnología (CNB-CSIC), Darwin 3, \\ Campus UAM Cantoblanco, 28049 Madrid, Spain; ngonzalez@cnb.csic.es \\ * Correspondence: imerida@cnb.csic.es
}

Received: 18 May 2020; Accepted: 10 June 2020; Published: 15 June 2020

\begin{abstract}
Recognition of antigens displayed on the surface of an antigen-presenting cell (APC) by T-cell receptors (TCR) of a T lymphocyte leads to the formation of a specialized contact between both cells named the immune synapse (IS). This highly organized structure ensures cell-cell communication and sustained T-cell activation. An essential lipid regulating T-cell activation is diacylglycerol (DAG), which accumulates at the cell-cell interface and mediates recruitment and activation of proteins involved in signaling and polarization. Formation of the IS requires rearrangement of the cytoskeleton, translocation of the microtubule-organizing center (MTOC) and vesicular compartments, and reorganization of signaling and adhesion molecules within the cell-cell junction. Among the multiple players involved in this polarized intracellular trafficking, we find sorting nexin 27 (SNX27). This protein translocates to the T cell-APC interface upon TCR activation, and it is suggested to facilitate the transport of cargoes toward this structure. Furthermore, its interaction with diacylglycerol kinase $\zeta(\mathrm{DGK} \zeta$ ), a negative regulator of DAG, sustains the precise modulation of this lipid and, thus, facilitates IS organization and signaling. Here, we review the role of SNX27, DAG metabolism, and their interplay in the control of T-cell activation and establishment of the IS.
\end{abstract}

Keywords: diacylglycerol; diacylglycerol kinase; SNX27; retromer; immune synapse; intracellular trafficking

\section{Introduction}

The immune synapse (IS) consists on a highly organized, dynamic macromolecular structure that enables cell-cell communication between immune cells. The formation of this tight cellular contact between antigen-presenting cells (APCs) and T cells is extensively studied. Nevertheless, this structure is also formed in other immune events, for example, between B lymphocytes and APCs [1] or during the engagement of cytotoxic T lymphocytes (CTL) or natural killer (NK) cells with infected/tumor cells for their clearance [2,3]. T-cell receptor (TCR) recognition of an antigen on an APC leads to remodeling of the actin and microtubule cytoskeletons, resulting in an evident change in T-cell morphology and the initial formation of the IS. Under these conditions, the microtubule-organizing center (MTOC) translocates to the T cell-APC contact surface, followed by the Golgi apparatus, endoplasmic reticulum, mitochondrial network, and endosomal compartments [4-6].

Vesicular trafficking to the IS plays a crucial role in IS assembly and function [7]; upon T-cell activation, signaling molecules organized in microclusters, as well as scaffold and adhesion proteins, traffic toward the IS and segregate in discrete supramolecular activation clusters (SMACs). The differential distribution of these molecules facilitates the spatio-temporal regulation of downstream signaling pathways, as well as the T-cell's effector functions [8-11]. Intracellular trafficking also mediates the polarized secretion of cytokines, lytic granules, and other cargoes toward the APC, regulating cell-cell communication [12-16]. Endosomal recycling represents the main mechanism via 
which $\mathrm{T}$ lymphocytes sustain continuous expression of receptors and signaling components at the IS. Sorting of internalized cargoes from early endosomes to recycling endosomes and Golgi favors polarized trafficking at the cell-cell interface in a mechanism that involves multiple proteins and phospholipids [17]. The evolutionary conserved endosomal retromer complex, in cooperation with several sorting nexin (SNX) proteins, such as SNX27, rescues transmembrane proteins from degradation and regulates their recycling [18]. The interaction of the retromer with the Wiskott-Aldrich syndrome protein and SCAR homolog complex (WASH) facilitates the nucleation of F-actin, promoting retrograde transport from early endosomes [19]. WASH deficiency in T lymphocytes results in impaired TCR trafficking and signaling defects [20]. Nevertheless, not all cargoes require the retromer for their recycling and SNX alone or additional machineries such as the retriever, which uses SNX17 for cargo recognition, or CCC complexes facilitate this process [21-24]. Although not too much is known about the retriever in IS formation, SNX17 is found with the TCR at the IS, and its silencing limits TCR and lymphocyte function-associated antigen 1 (LFA-1) expression at the cell surface, affecting IS formation and T-cell activation [25]. Contrary to their recycling, cargoes can also be transported to lysosomes for their degradation, which is achieved via the activity of endosomal sorting complexes required for transport (ESCRT) [26,27]. Phospholipids are important players of membrane trafficking, as they control physical features of membranes directly, through the recruitment of proteins or by regulating cytoskeleton-associated molecules [28,29]. Particular phospholipids named phosphoinositides (PI) work together with Rab GTPases, regulatory proteins that recruit effectors involved in the formation of vesicles, as well as their traffic and fusion. Furthermore, both types of molecules define endosomal and organelle identity [30-32]. When PI, Rab GTPases, and their effector proteins bring membranes in close proximity, soluble NSF (N-ethylmaleimide-sensitive factor) attachment protein receptor (SNARE) proteins go into action and mediate their fusion [33,34].

All in all, intracellular trafficking is essential for establishment of the IS and maintenance of its associated signaling. The distinct trafficking steps acting together to regulate this process involve multiple players. Here, we summarize the current knowledge of the roles of lipids, with a special focus on the lipid second messenger diacylglycerol (DAG), as well as that of the transport protein SNX27, in the spatio-temporal regulation of trafficking and signaling that sustains the IS.

\section{Diacylglycerol and Phosphatidic Acid in the Regulation of the Immune Synapse}

DAG is a lipid with critical functions in lipid metabolism and signaling. Recognition of antigens by $\mathrm{T}$ lymphocytes results in the rapid generation of DAG that is maintained and restricted to the cell-cell interface, facilitating the recruitment and modulation of proteins involved in T-cell polarization, immune synapse formation, and signaling [35]. Upon T cell-APC engagement phospholipase $C \gamma 1$ (PLC- $\gamma 1)$-mediated hydrolysis of phosphatidylinositol (PtdIns) $(4,5)$-bisphosphate $\left(\operatorname{Ptd} \operatorname{Ins}(4,5) \mathrm{P}_{2}\right)$ leads to the production of inositol triphosphate $\left(\mathrm{IP}_{3}\right)$ and DAG [36]. $\mathrm{IP}_{3}$ triggers the release of stored intracellular $\mathrm{Ca}^{2+}$ and activation of nuclear factor of activated $\mathrm{T}$ cells (NFAT)-mediated transcription $[37,38]$. DAG generation facilitates IS recruitment and activation of proteins containing DAG-binding type 1 PKC (C1) domains such as guanyl nucleotide-releasing protein for Ras1 (RasGRP1) and protein kinase $C \alpha(P K C \alpha)$, that link the DAG generated at the IS to the intensity of Ras/ERK activation and activator protein 1 (AP-1)-dependent transcription [39-42]. DAG also binds and activates other PKC isoforms, like PKC $\theta$, connecting DAG production to the regulation of the nuclear factor $\mathrm{kB}(\mathrm{NF}-\mathrm{kB})$ pathway [43], as well as to the activation of the PDK-1/AKT/mTOR axis [44], which is involved in the regulation of protein synthesis, cellular metabolism, and cell survival. DAG levels are tightly regulated by diacylglycerol kinases (DGKs), which phosphorylate it into phosphatidic acid (PA), limiting recruitment of DAG effectors and the activation of downstream signaling pathways [35] (Figure 1A). In T lymphocytes, the main DGK isoforms contributing to DAG attenuation are type I DGK $\alpha$ and type IV DGK $[45,46]$. 
A

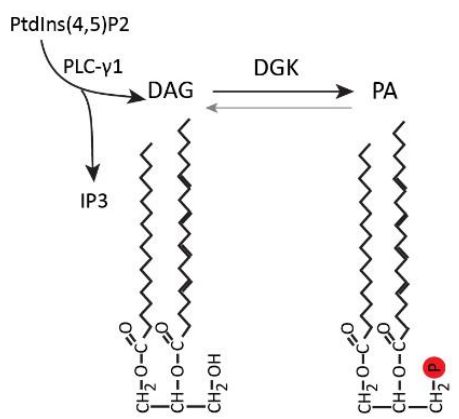

B

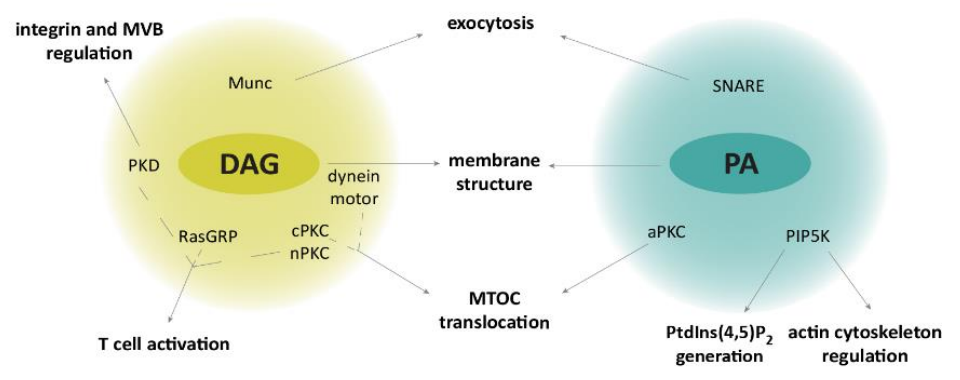

Figure 1. Diacylglycerol (DAG) metabolism contributes to immune synapse (IS) structure and associated signaling. (A) Upon T-cell activation, PLC- $\gamma 1$-mediated phosphatidylinositol $(4,5)$-bisphosphate (PtdIns $\left.(4,5) \mathrm{P}_{2}\right)$ hydrolysis leads to the generation of inositol triphosphate $\left(\mathrm{IP}_{3}\right)$ and DAG, which in turn can be converted to phosphatidic acid (PA) via the activity of a diacylglycerol kinase (DGK). (B) Schematic representation of proteins recruited and modulated by DAG and PA at the synapsis of T lymphocytes, indicating the cellular processes in which they are involved. MVB, multivesicular bodies; nPKC, novel protein kinase C (PKC); cPKC, conventional PKC; aPKC, atypical PKC.

One of the characteristic events in IS formation is the translocation of the MTOC to the T cell-APC contact area. Although the exact mechanisms governing the dynamics of this event are not completely understood, DAG accumulation at the IS is followed by MTOC translocation, and it is sufficient to induce this process independent of the TCR. Inhibition of PLC- $\gamma 1$ activity impairs MTOC translocation [47], whereas sequential DAG-dependent recruitment of PKC $\varepsilon, \eta$, and $\theta$ facilitates MTOC localization to the IS. Indeed, small interfering RNA (siRNA)-silencing of PKC $\theta$ alone or the combination of $\mathrm{PKC} \varepsilon+\mathrm{PKC} \eta$ impaired this process [48]. Although the precise procedure via which the distinct PKC isoforms contribute to MTOC translocation is not yet known, their role in regulating dynein and myosin motors is likely involved [49]. Interestingly, failure to form a stable DAG gradient by DGK inhibition or addition of the DAG analogue phorbol-12-myristate-13-acetate (PMA) impaired both dynein recruitment and MTOC translocation $[47,49]$.

Remarkably, DAG accumulation influences other aspects of the IS structure and signaling. For instance, dynein motors recruited to DAG-enriched areas associate with TCR microclusters and mediate their transport toward the central region of the IS [50,51]. Furthermore, these motors facilitate the localization of integrins in the peripheral area, providing an adhesive ring that stabilizes the T cell-APC conjugate [52]. DAG also drives the activation and polarization of the serine/threonine kinase PKD (protein kinase D, also known as protein kinase $C \eta(P K C \eta)$ ) to the IS [53]. Activated PKD was shown to regulate the activity and clustering of $\beta 1$ integrin induced by T-cell stimulation [54], cell proliferation, and TCR signaling via crosstalk with the DAG-PKC axis [55]. Moreover, PKD is involved in the maturation, polarized transport, and secretion of multivesicular bodies toward the IS [56]. Furthermore, other C1-containing proteins like mammalian unc (Munc) proteins, which regulate neurotransmitter release in the brain [57-60], participate in the control of lytic granule secretion by CTL and NK cells, and their defect is associated with human immunodeficiencies [61-65]. These proteins likely mediate exocytosis at the synapse by facilitating assembly of SNARE complexes required for vesicle fusion.

PA-mediated functions at the IS remain largely unknown. This DAG metabolite recruits phosphatidylinositol 4-phosphate 5-kinase (PIP5K) to the plasma membrane, promoting PtdIns $(4,5) \mathrm{P}_{2}$ generation [66-68]. A recent study showed that PA is evenly distributed across the plasma membrane of CTL and appears to remain unchanged during IS formation with target cells [69]. Additionally, it was revealed that the recruited PIP5K regulates the actin cytoskeleton at the IS, facilitating targeted granule secretion by the CTL. PA-regulated exocytosis was previously described in a variety of cell types including neutrophils and neurons [70,71], and it was mentioned to be facilitated by PA's conical shape, which induces negative membrane curvatures, as well as its participation in the modulation of 
SNARE complexes [72-74]. These data suggest that PA, as DAG, may be influencing membrane IS structure and function.

All in all, these studies highlight the importance of the spatio-temporal regulation of DAG metabolism in the recruitment of effector proteins and generation of PA, which in turn influence immune synapse signaling and structure (Figure 1B).

\section{Diacylglycerol Kinase $\zeta$ Modulates Diacylglycerol Abundance and Associated Signaling at the Immune Synapse}

As mentioned in the previous section, DGK catalyzes the phosphorylation of DAG to PA, limiting DAG-regulated functions [35]. The 10 mammalian DGK isoforms described to date are classified into five groups $(\mathrm{I}-\mathrm{V})$ based on the presence of specific regulatory domains within their sequences. All isoforms include a catalytic domain and have at least two conserved $\mathrm{C} 1$ domains. Nevertheless, only some of these $\mathrm{C} 1$ domains enclose the necessary residues to bind DAG, and the mechanism of interaction with this lipid remains to be elucidated [75]. Type I DGK $\alpha$ and type IV DGK $\zeta$ are the two isoforms expressed in T lymphocytes [45,46]. As observed for DAG, these kinases translocate to the IS following TCR/CD28 engagement and contribute to regulate the levels of this lipid [76,77]. This ensures an adequate regulation of TCR signal intensity and duration.

Despite displaying overlapping intracellular localizations and redundant roles, DGK $\zeta$ was shown to exert a stronger negative function over DGK $\alpha$ in activated $\mathrm{T}$ cells by limiting PKC $\theta / \mathrm{PDK}-1$ mutual activation. This provides negative regulation not only of the NFKB axis, but also of the PDK-1/AKT/mTOR/S6K pathway [78]. Furthermore, this DGK isoform has a predominant role in terminating the RasGRP1/Ras/ERK pathway downstream of the TCR [46,79-81]. Indeed, our group showed that DGK $\zeta$ controls DAG metabolism at the IS and negatively regulates PKC $\alpha$ translocation, a DAG effector involved in Ras/ERK activation [42,76]. Among the specialized functions of DGK $\zeta$ we also found that it limits cytokine-mediated expansion of innate-like CTL independent of antigen stimulation [82]. All these findings correlate with studies in DGKל-deficient mice presenting enhanced anti-tumoral responses, which are not observed in DGK $\alpha$-deficient mice [82-84].

In agreement with the role of DGK $\alpha$ and DGK $\zeta$ in the modulation of DAG at the IS, several studies showed substantial defects in IS organization as a result of DGK $\alpha$ or DGK $\zeta$ deficiency. For instance, stimulated $\mathrm{CD}^{+} \mathrm{T}$ cells treated with DGK inhibitors or deficient for DGK $\alpha$ present destabilized synaptic DAG accumulation and impaired MTOC recruitment $[47,77]$. Moreover, DGK $\zeta$-deficient CTL show an impairment in MTOC docking to the IS, which correlates with a reduced translocation of phosphorylated PKC $\zeta$ [85]. PKC $\zeta$ is known to be regulated by DGK-derived PA in non-T cells [86], and it was shown to promote MTOC polarization in primary $\mathrm{CD}^{+}$and $\mathrm{CD} 8^{+} \mathrm{T}$ cells $[87,88]$, suggesting a role for the DGK $\zeta / \mathrm{PA} / \mathrm{PKC} \zeta$ axis in this process. Remarkably, the impact of this kinase is not limited to $T$ cells, as DGK $\zeta$-mediated PA production was shown to play a role in the assembly of the B-cell IS, regulating actin remodeling, MTOC translocation, force generation, and antigen-uptake related processes [89].

\section{Sorting Nexins in Membrane Trafficking}

\subsection{SNX-FERM and SNX-BAR Subfamilies}

The sorting nexin (SNX) family is composed of proteins involved in the regulation of intracellular trafficking and endosomal signaling $[18,90,91]$. They are characterized by the presence of a phox homology (PX) domain, which is involved in phosphoinositide binding. Thus, it targets SNX to endosomal membranes, most commonly by binding to PtdIns(3)P [92,93]. Additionally, accumulating evidence demonstrates the PX domain's ability to engage in protein-protein interactions, although its functional importance in SNX is still not clear [93]. To date, 33 mammalian SNX proteins were identified, and they are divided into subfamilies based on the presence of different structural domains. 
Given their relevance in membrane trafficking, we proceed to describe SNX-BAR (Bin, amphiphysin, Rvs) and SNX-FERM (4.1/ezrin/radixin/moesin) subfamilies.

SNX17, SNX31, and SNX27 form the SNX-FERM subfamily, which is characterized by the presence of an atypical C-terminal FERM domain, named the FERM-like domain. Comparable to the typical one, it contains F1, F2, and F3 modules, although the F2 sequence is shorter [92]. The F1 module resembles a Ras-association domain (RA) to which small GTPases from the Ras-like protein family bind. Additional contacts of these molecules with the F2 module may contribute to binding specificity. In vitro, all SNX FERM domains bind to H-Ras, although cell biology studies later functionally linked the SNX27 FERM domain to K-Ras [92,94,95]. The existence of additional Ras isoforms interacting with SNX FERM domains in vivo remains to be examined. Peptide array screening revealed that the F3 module specifically interacts with cargoes containing NpxY/NxxY motifs with a preference for sequences phosphorylated at $Y_{0}$ in the case of SNX27. Of note, in vivo studies only demonstrated a role for SNX17 and SNX31 in the recycling of NpxY/NxxY-containing transmembrane proteins, preventing their lysosomal degradation $[21,25,96-100]$. All in all, these data indicate that SNX-FERM proteins are involved in endosomal cargo recycling and act as scaffolds for signaling complexes.

SNX-BAR proteins are defined by the presence of a BAR domain and include SNX1-SNX9, SNX18, SNX30, SNX32, and SNX33 [93]. The lipid-binding BAR domain is a protein dimerization motif which senses and binds positive membrane curvatures, promoting their tubulation [101-103]. Furthermore, members of this subfamily form part of the retromer complex and participate in intracellular cargo trafficking [103-105]. The retromer complex, firstly identified in Saccharomyces cerevisiae, is formed by a cargo-selection subcomplex (CSC) and a membrane-deforming subcomplex [106]. In mammals, the CSC is conserved and is formed by Vps35, Vps29, and Vps26A/Vps26B proteins [107-109], while the membrane-deforming subcomplex includes the SNX-BAR heterodimer of SNX1/SNX2 with SNX5/SNX6/SNX32 [106]. Nevertheless, the CSC was also described to bind the non-BAR domain containing SNX3, as well as SNX27, leading to different retromer structures [91]. The retromer plays a key role in the regulation of endosome-to-trans-Golgi transport and endosome-to-plasma membrane recycling, preventing cargo degradation [110-112]. This tubular-based endosomal sorting is facilitated by retromer's association to cytoskeleton components such as the motor dynein/dynactin complex or the WASH complex, which is involved in promoting actin polymerization [113-115].

\subsection{The SNX27-Retromer Multiprotein Complex Is Involved in Protein Recycling}

Like all members of the SNX-FERM subfamily, SNX27 contains a PX domain and a FERM-like domain. Additionally, it includes an N-terminal postsynaptic density 95/discs large/zonula occludens-1 (PDZ) domain which makes it unique within the SNX. The PDZ domain simultaneously binds to PDZ-binding motif-containing proteins and the Vps26 subunit of the retromer complex, which enhances cargo binding affinity and favors their recycling $[114,116]$. The PX domain mediates SNX27 localization to PtdIns(3)P-enriched endosomal membranes. Meanwhile, the FERM-like domain can recruit cargoes containing NpxY/NxxY motifs in vitro, engage K-Ras in a GTP-dependent manner [92,95], and bind bi- and tri-phosphorylated PI [117]. Moreover, this domain interacts with SNX-BAR proteins and the WASH complex $[114,115]$, which in turn maintains the integrity of the endosomal and lysosomal network by regulating actin polymerization $[19,118,119]$. SNX-BARs and the WASH complex also indirectly recruit SNX27 to the retromer and situate it as a core component of the SNX27-retromer multiprotein complex [120,121] (Figure 2A).

In this situation, SNX27 acts as an adaptor protein which links cargo recognition through its PDZ domain and likely through the FERM-like domain to retromer-mediated endosomal transport. This allows cargoes recycling to the plasma membrane, preventing their sorting into the lysosomal degradative pathway [112,114,115] (Figure 2B,C). Some examples include the $\beta 2$-adrenergic receptor [115,122], the glucose transporter 1 (GLUT1) [114], the G-protein-gated potassium (Kir3) channel [123], or the glutamine transporter (alanine, serine, cysteine transporter 2 (ASCT2)) [124]. 
A

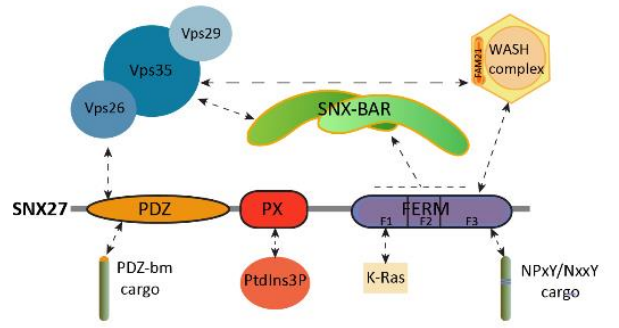

B

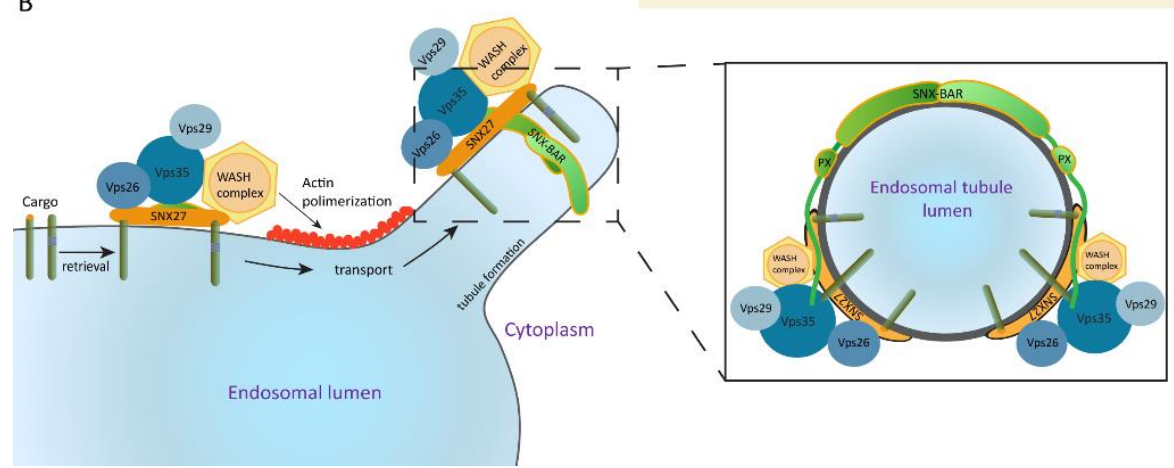

C

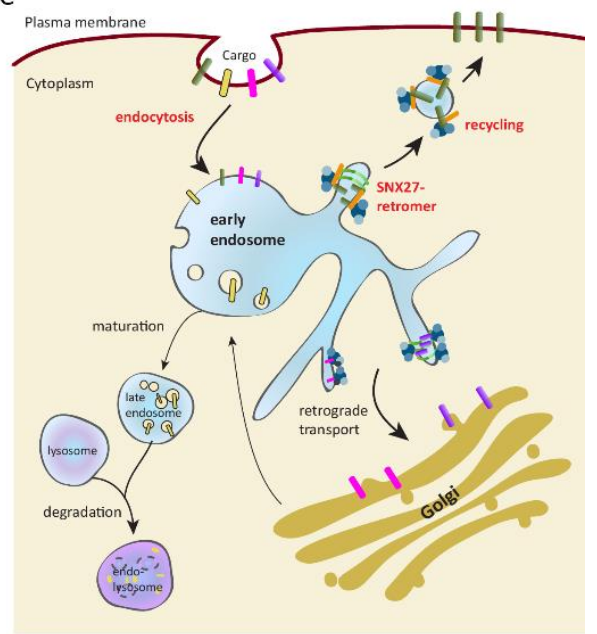

Figure 2. Sorting nexin 27 (SNX27)-retromer architecture and function in intracellular trafficking. (A) SNX27 establishes N-terminal postsynaptic density 95/discs large/zonula occludens-1 (PDZ) domain-mediated interactions with cargo and the Vps26 retromer subunit, as well as 4.1/ezrin/ radixin/moesin (FERM) domain-dependent engagement with the retromer SNX-BAR (Bin, amphiphysin, Rvs) and the Wiskott-Aldrich syndrome protein and SCAR homolog (WASH) complex. Moreover, both the SNX-BAR dimer and the WASH complex directly bind to the cargo selection subcomplex of the retromer. (B) SNX27-retromer promotes endosomal trafficking of cargo to the plasma membrane; this multiprotein complex is associated to the cytosolic face of the endosomal membrane mainly through binding of the SNX27 phox homology (PX) domain and SNX-BARs to phosphoinositides (PI). Endosomal localization is further stabilized by SNX27 cargo recognition and cargo-selection subcomplex (CSC) interaction with SNX-BAR and SNX27. Actin polymerization mediated by the WASH complex and membrane remodeling induced by SNX-BAR mediate tubule formation and scission of the cargo-enriched endosome subdomain. A frontal view of the endosomal tubule coated by the SNX27-retromer is shown. Images modified from References [17,112]. (C) The generated cargo-loaded vesicles are subsequently recycled to the cell surface, preventing their lysosomal degradation. Image modified from Reference [111].

\section{SNX27 in the Regulation of the Immune Synapse}

Our laboratory identified SNX27 expression in T lymphocytes in a proteomic analysis that searched for PDZ-interacting DGK $\zeta$ partners [125]. In resting T lymphocytes, SNX27 localizes at early and recycling endosomes mainly through the interaction of its PX domain with PtdIns(3)P [125]. Upon antigen presentation by an APC, these SNX27-enriched compartments rapidly polarize toward the cell-cell interface with an important SNX27 fraction accumulating at the central and peripheral SMAC (c-SMAC and p-SMAC) of the IS (Figure 3). This polarized trafficking is mediated by the binding of the PX domain to PtdIns(3)P and the FERM domain to PtdIns(4,5) $\mathrm{P}_{2}$ - and/or PtdIns(3,4,5) $\mathrm{P}_{3}$-enriched membrane regions $[117,126]$. The SNX27 PDZ domain also influences this process, although the 
specific PDZ-binding motif-containing cargoes directing SNX27 recruitment to the IS still remain unknown [126,127].

The participation of SNX27-retromer in intracellular trafficking and its accumulation at the IS suggest a role in the transport of cargo to the cell-cell interface. Proteomic analysis of the SNX27 interactome from IS-forming T cells confirmed its association with DGK $\zeta$, the retromer and WASH complexes, and additional cargoes that associate to SNX27 to traffic to the IS [127]. These include the protein zonula occludens-2 ( $\mathrm{ZO}-2)$, a constituent of tight junctions never before identified in $\mathrm{T}$ lymphocytes, centromere protein J (CENPJ), which is part of the centrosome, or the Rho guanine nucleotide exchange factor 7 (ARHG7, also known as $\beta$ p21-activated kinase-interactive exchange factor ( $\beta$-PIX)) among others. ZO-2 mobility at the IS was decreased in SNX27-silenced T cells, consistent with the idea that SNX27 coordinates polarized trafficking toward this structure (Figure 3). Unlike that observed in other cell systems, PDZ-interacting SNX27 cargoes during IS formation were proteins with functions in cytoskeletal remodeling, cell adhesion, and/or centrosome organization, suggesting that SNX27 functions as a signaling scaffold in T cells, likely constituting an important regulator of activation at the IS. This role is facilitated by its specific structural composition; the F1 module of the FERM domain binds to GTPases from the Ras-like protein family [92,95], while the PDZ domain interacts with scaffolds and signaling complexes. For instance, it engages cytohesin-associated scaffolding protein (CASP), which regulates signaling through the ADP-ribosylation factor (ARF) family of small GTPases [128] or Kidins220, a scaffold that promotes ERK signaling [129].

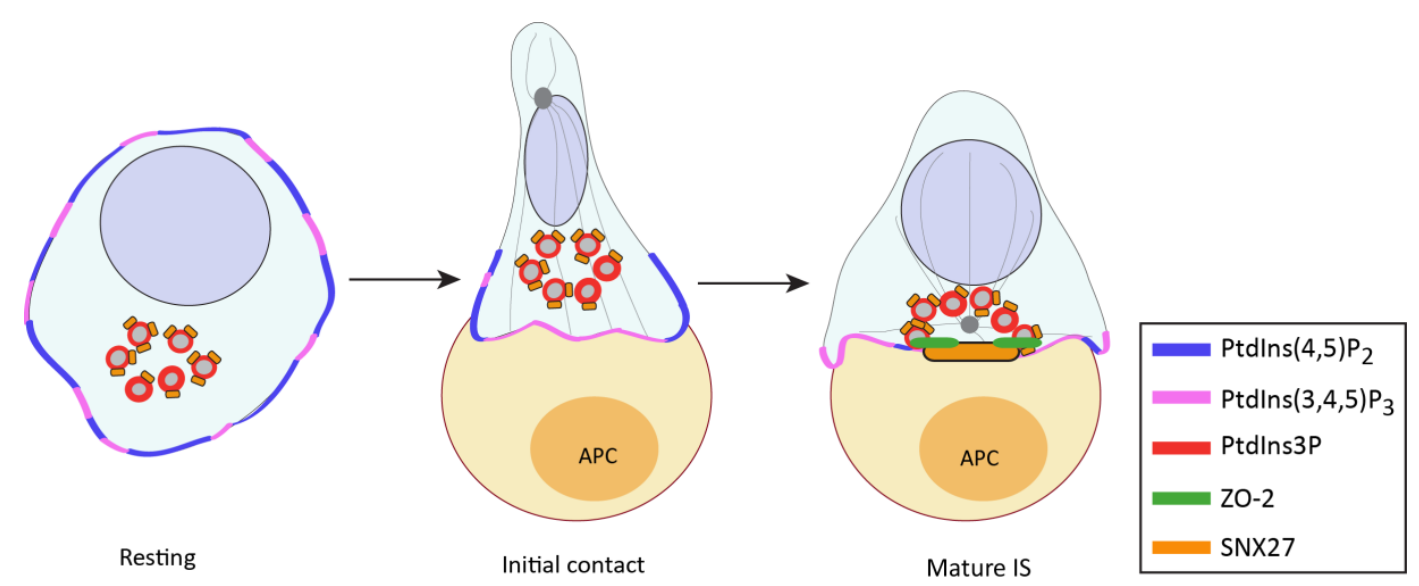

Figure 3. SNX27 is recruited to the IS and facilitates trafficking of cargoes toward this structure. In resting T cells, SNX27 is mainly found at PtdIns(3)P-positive endosomes. Upon T-cell activation, these endosomes polarize toward the cell-cell interface, and a fraction of this protein accumulates at the IS. This event is facilitated by the SNX27 PDZ domain and the interaction of its FERM domain with PtdIns $(4,5) \mathrm{P}_{2}$ - and/or PtdIns $(3,4,5) \mathrm{P}_{3}$-enriched membrane regions. Binding of SNX27 to its cargoes can drive their mobility to the IS, as observed for zonula occludens-2 (ZO-2).

Immune synapses not only resemble neuronal synapses in morphology, but they also share common transport mechanisms. Indeed, release of secretory vesicles at the IS is highly similar to neurotransmitter delivery from neurons and neuroendocrine cells [130]. Remarkably, SNX27 is also present in neurons, where it was described to play a key role facilitating PDZ-mediated recycling of cargoes, such as glutamate receptors $[95,131]$. The importance of this complex is underscored by the fact that SNX27 deficiency or mutation is associated with synaptic dysfunction and a variety of neurological diseases such as Alzheimer's disease or Down syndrome [131,132]. Additionally, recent studies suggested that SNX27-retromer-mediated trafficking favors breast cancer metastasis [133,134]. Therefore, further research on SNX27 will shed light on immune and neuronal function and dysfunction, as well as increase the understanding of tumor invasiveness. 


\section{SNX27 Interacts with DGK $\zeta$ and Modulates Diacylglycerol Metabolism at the Immune Synapse}

Structural studies of PDZ-based SNX27 and cargo interaction demonstrated that this binding can be of high or low affinity based on the amino-acid sequence upstream of their PDZ-binding motif. High-affinity engagement to SNX27 requires cargoes containing acidic residues located at the -3 and -5 positions, which are able to clamp a conserved arginine on the SNX27 surface. Nevertheless, cargoes that lack these acidic residues, but instead present conserved phosphorylation sites, can also undergo high-affinity binding to SNX27 upon phosphorylation of these residues [135]. In agreement with our identification of SNX27 association with DGK $\zeta$ in T cells [125], biophysical and biochemical analyses confirmed that the DGK $\zeta$ terminal sequence EDQETAV promotes a high-affinity interaction with the SNX27 PDZ domain [135] (Figure 4A).

The best-known function of SNX27-retromer is to promote recycling of PDZ-binding transmembrane cargoes, preventing their degradation. Consequently, SNX27 silencing is reported to enhance degradation of many of its binding partners, as observed for GLUT1 [114]. However, we did not detect significant changes in DGK $\zeta$ protein levels in SNX27-silenced cells, suggesting that this interaction is not required to maintain DGK $\zeta$ expression but its spatial localization [136].

A

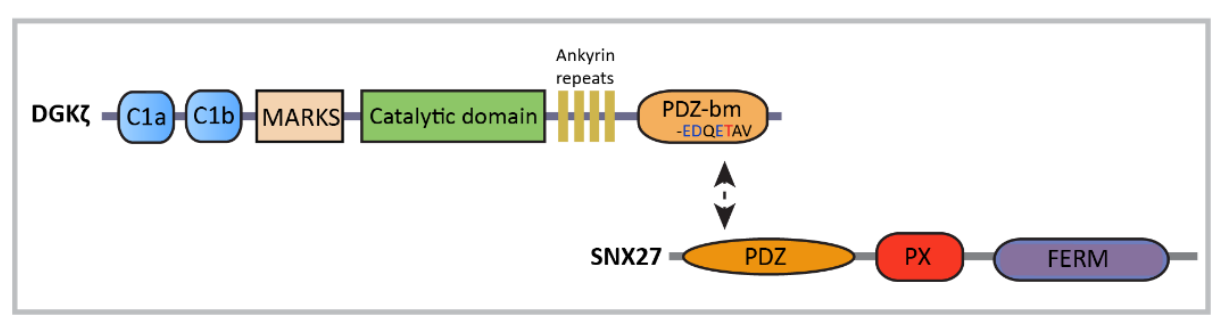

B

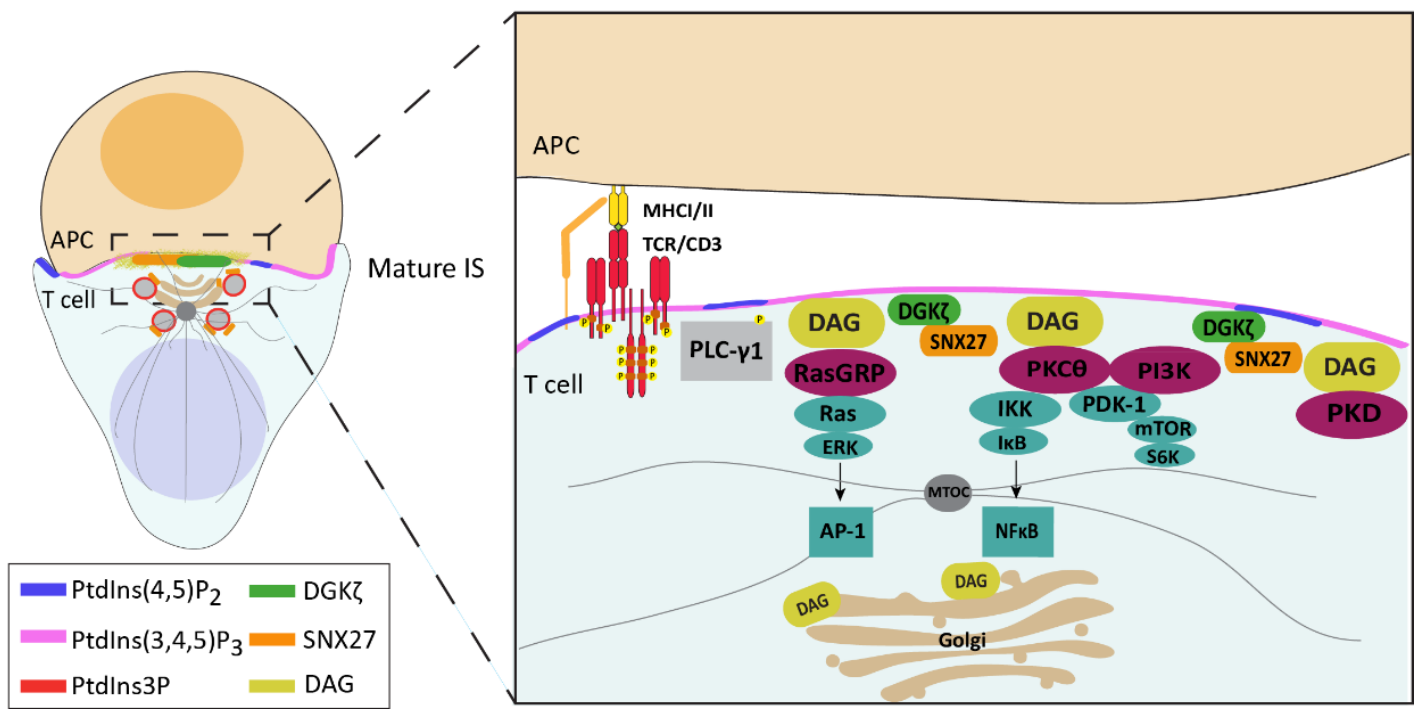

Figure 4. SNX27 participates in the regulation of DAG metabolism at the IS through interaction with

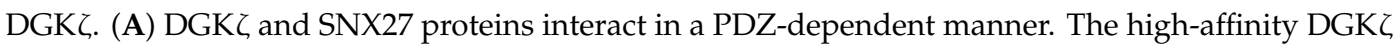
C-terminal sequence EDQETAV with possible phosphorylation sites (red) and positively charged amino acids (blue) is indicated. (B) Engagement of antigen-TCR triggers PLC- $\gamma 1$ activation, resulting in DAG production and its accumulation at the IS. Likewise, SNX27 and the DAG-negative regulator DGK $\zeta$ translocate to the IS simultaneously with PtdIns $(3,4,5) \mathrm{P}_{3}$ and DAG generation. SNX27 sustains the stability and localization of this kinase, facilitating the regulation of DAG and its downstream signaling pathways. 
The identification of a PDZ-mediated interaction of SNX27 with DGK $\zeta$ and the finding that these proteins accumulate at the IS following T-cell stimulation prompted us to study the participation of SNX27 in the modulation of DAG-regulated pathways upon TCR antigen recognition (Figure 4B). Research from our group revealed that silencing of either SNX27 or DGK $\zeta$ in antigen-stimulated T cells results in increased ERK phosphorylation, suggesting a functional connection between these two proteins [126]. Moreover, SNX27 silencing results in NF- $\kappa B$ hyperactivation upon TCR co-stimulation that does not further increase following additional DGK $\zeta$ downregulation $[78,136]$. Although these data suggest redundant functions for SNX27 and DGK $\zeta$ in T-cell signaling, it is worth mentioning that SNX27 may modulate T-cell activation via interaction with additional cargoes. For instance, TCR co-stimulation of DGK $\zeta$-silenced cells promotes PKC $\theta$ interaction with PDK1 and subsequent mTOR signaling activation [78], while SNX27 silencing downregulates this pathway [136]. The decreased mTOR activation in SNX27-silenced cells correlated with defective antigen-induced growth of naïve T cells from $\operatorname{Sn} \times 27^{-/-}$mice. This raises the possibilities that SNX27 silencing either potentiates DGKC inhibitory function on the mTOR pathway or disrupts interaction of SNX27 with cargoes that favor mTOR activation independent of DGK $\zeta$.

In summary, the identification of SNX27 as a DGK $\zeta$-interacting partner that facilitates its strict spatial and temporal regulation during IS formation offers new insight into the precise modulation of DAG metabolism and signaling during T-cell activation (Figure 4B). Adequate equilibrium of DAG and PA not only favors regulation of signaling molecules, but it also modulates proteins involved in polarization and intracellular transport, and it contributes to inducing negative membrane curvatures, important for membrane fission and fusion [72]. Further research will be needed to determine the extent to which SNX27 regulation of DAG metabolism impacts IS formation and efficiency.

\section{Concluding Remarks}

Precise regulation of intracellular transport is particularly crucial in polarized cells, which depend on active membrane trafficking at specific sites to carry out their functions [137-139]. In T cells, polarized membrane trafficking facilitates T-cell surveillance, surface display of receptors, as well as adhesion and signaling molecules, and release of cytokines and other cargo to the immunological synapse $[7,137]$. Indeed, loss of polarity is associated with impaired signaling competence. Numerous players are involved in the regulation of these processes, with a remarkable participation of lipids.

The findings summarized in this review highlight the important contribution of SNX27 in the regulation of DAG metabolism and the influence of these molecules in intracellular trafficking and signaling for establishment and maintenance of the IS. Although we only offer a view of the T-cell side of the IS, localized trafficking also occurs at the APC side and greatly influences the stability and activity of this structure [140,141]. Thus, it will be of great interest to investigate if these molecules also play a role in the polarization and signaling triggered in the APC. Furthermore, some findings on SNX27 and DAG dynamics during IS formation could be extrapolated to other models of polarized trafficking such as invadopodia formation or the neuronal synapse, where SNX27 is associated with numerous pathological conditions [131-134].

Author Contributions: Writing—original draft preparation, N.G.-M.; writing—review, I.M.; preparation of figures, N.G.-M. All authors read and agreed to the published version of the manuscript.

Funding: The work of Natalia González-Mancha received funding from the European Union Horizon 2020 research and innovation program under the Marie Sklodowska-Curie grant agreement No. 713673 and "La Caixa" Foundation (ID 100010434). The fellowship code is LCF/BQ/DI17/11620027. Research in Merida's lab is funded by grants from the Spanish Association Against Cancer (AECC, CICPF18), Aplastic Anemia and MDS International Foundation (AAMDSIF, OPE01644), Spanish Ministry Economy and Competitiveness co-financed by the European Regional Development Fund (BFU2016-77207-R), and the Madrid regional government (IMMUNOTHERCAM Consortium S2010/BMD-2326) to I.M.

Acknowledgments: We thank Javier Arranz and Cristina Rodríguez for critical reading of the manuscript.

Conflicts of Interest: The authors declare no conflicts of interest. 


\section{Abbreviations}

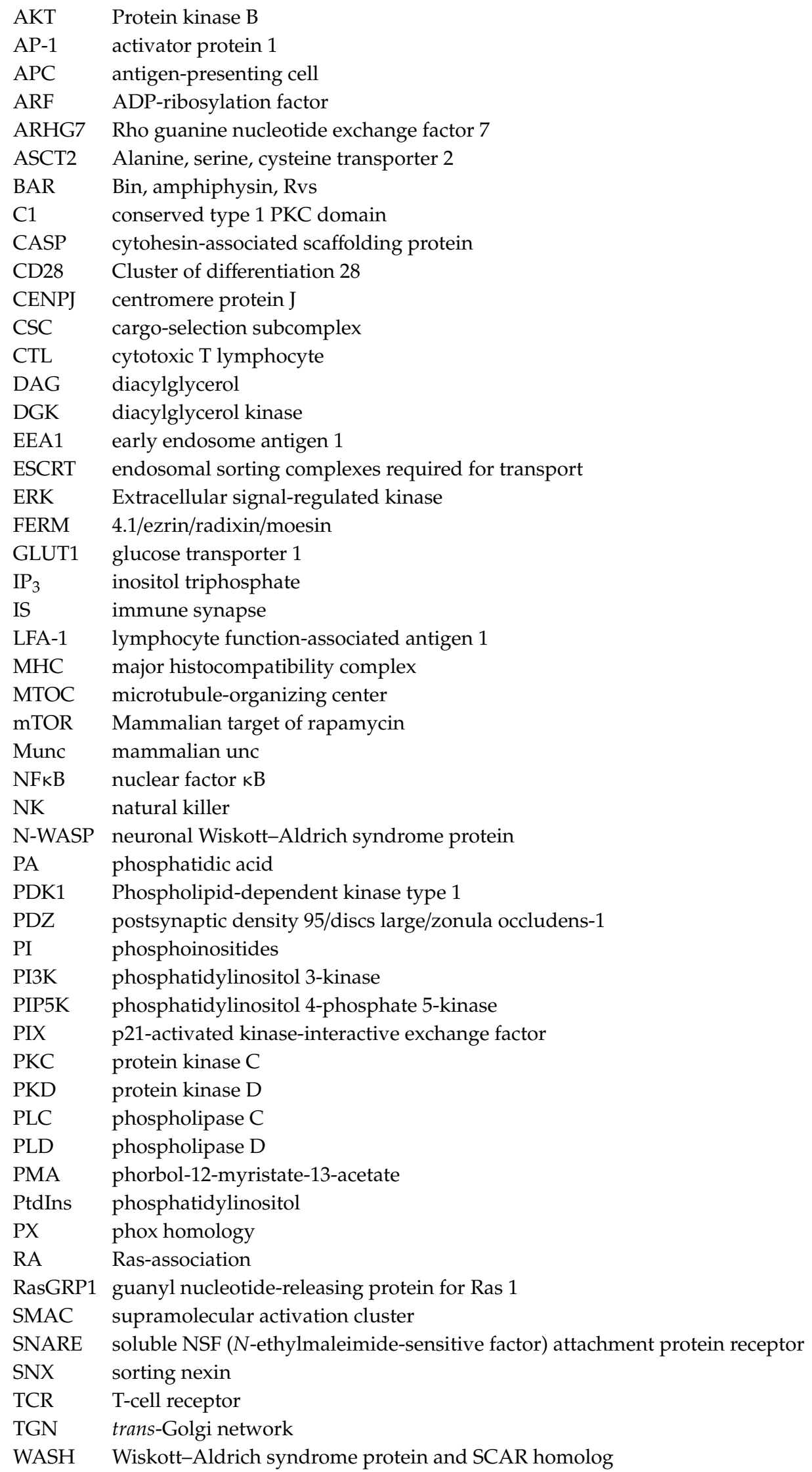

WASH Wiskott-Aldrich syndrome protein and SCAR homolog 


\section{References}

1. Batista, F.D.; Iber, D.; Neuberger, M.S. B cells acquire antigen from target cells after synapse formation. Nature 2001, 411, 489-494. [CrossRef] [PubMed]

2. Davis, D.M.; Chiu, I.; Fassett, M.; Cohen, G.B.; Mandelboim, O.; Strominger, J.L. The human natural killer cell immune synapse. Proc. Natl. Acad. Sci. USA 1999, 96, 15062-15067. [CrossRef] [PubMed]

3. Stinchcombe, J.C.; Bossi, G.; Booth, S.; Griffiths, G.M. The Immunological Synapse of CTL Contains a Secretory Domain and Membrane Bridges. Immunity 2001, 15, 751-761. [CrossRef]

4. Alcover, A.; Thoulouze, M.-I. Vesicle Traffic to the Immunological Synapse: A Multifunctional Process Targeted by Lymphotropic Viruses. In Immunological Synapse; Saito, T., Batista, F.D., Eds.; Current Topics in Microbiology and Immunology; Springer Berlin Heidelberg: Berlin/Heidelberg, Germany, 2010; Volume 340, pp. 191-207, ISBN 978-3-642-03857-0.

5. Martín-Cófreces, N.B.; Baixauli, F.; Sánchez-Madrid, F. Immune synapse: Conductor of orchestrated organelle movement. Trends Cell Biol. 2014, 24, 61-72. [CrossRef]

6. Kupfer, A.; Singer, S.J. The specific interaction of helper T cells and antigen-presenting B cells. IV. Membrane and cytoskeletal reorganizations in the bound $\mathrm{T}$ cell as a function of antigen dose. J. Exp. Med. 1989, 170, 1697-1713. [CrossRef] [PubMed]

7. Onnis, A.; Finetti, F.; Baldari, C.T. Vesicular Trafficking to the Immune Synapse: How to Assemble Receptor-Tailored Pathways from a Basic Building Set. Front. Immunol. 2016, 7. [CrossRef]

8. Monks, C.R.F.; Freiberg, B.A.; Kupfer, H.; Sciaky, N.; Kupfer, A. Three-dimensional segregation of supramolecular activation clusters in T cells. Nature 1998, 395, 82-86. [CrossRef]

9. Bunnell, S.C.; Hong, D.I.; Kardon, J.R.; Yamazaki, T.; McGlade, C.J.; Barr, V.A.; Samelson, L.E. T cell receptor ligation induces the formation of dynamically regulated signaling assemblies. J. Cell Biol. 2002, 158, 1263-1275. [CrossRef]

10. Yokosuka, T.; Sakata-Sogawa, K.; Kobayashi, W.; Hiroshima, M.; Hashimoto-Tane, A.; Tokunaga, M.; Dustin, M.L.; Saito, T. Newly generated T cell receptor microclusters initiate and sustain T cell activation by recruitment of Zap70 and SLP-76. Nat. Immunol. 2005, 6, 1253-1262. [CrossRef]

11. Campi, G.; Varma, R.; Dustin, M.L. Actin and agonist MHC-peptide complex-dependent T cell receptor microclusters as scaffolds for signaling. J. Exp. Med. 2005, 202, 1031-1036. [CrossRef]

12. Kupfer, A.; Mosmann, T.R.; Kupfer, H. Polarized expression of cytokines in cell conjugates of helper T cells and splenic B cells. Proc. Natl. Acad. Sci. USA 1991, 88, 775-779. [CrossRef] [PubMed]

13. Reichert, P.; Reinhardt, R.L.; Ingulli, E.; Jenkins, M.K. Cutting Edge: In Vivo Identification of TCR Redistribution and Polarized IL-2 Production by Naive CD4 T Cells. J. Immunol. 2001, 166, 4278-4281. [CrossRef] [PubMed]

14. Huse, M.; Lillemeier, B.F.; Kuhns, M.S.; Chen, D.S.; Davis, M.M. T cells use two directionally distinct pathways for cytokine secretion. Nat. Immunol. 2006, 7, 247-255. [CrossRef] [PubMed]

15. Huse, M.; Quann, E.J.; Davis, M.M. Shouts, whispers and the kiss of death: Directional secretion in T cells. Nat. Immunol. 2008, 9, 1105-1111. [CrossRef] [PubMed]

16. Mittelbrunn, M.; Gutiérrez-Vázquez, C.; Villarroya-Beltri, C.; González, S.; Sánchez-Cabo, F.; González, M.Á.; Bernad, A.; Sánchez-Madrid, F. Unidirectional transfer of microRNA-loaded exosomes from T cells to antigen-presenting cells. Nat. Commun. 2011, 2, 282. [CrossRef]

17. Bonifacino, J.S.; Rojas, R. Retrograde transport from endosomes to the trans-Golgi network. Nat. Rev. Mol. Cell Biol. 2006, 7, 568-579. [CrossRef]

18. Cullen, P.J. Endosomal sorting and signalling: An emerging role for sorting nexins. Nat. Rev. Mol. Cell Biol. 2008, 9, 574-582. [CrossRef]

19. Derivery, E.; Sousa, C.; Gautier, J.J.; Lombard, B.; Loew, D.; Gautreau, A. The Arp2/3 Activator WASH Controls the Fission of Endosomes through a Large Multiprotein Complex. Dev. Cell 2009, 17, 712-723. [CrossRef]

20. Piotrowski, J.T.; Gomez, T.S.; Schoon, R.A.; Mangalam, A.K.; Billadeau, D.D. WASH Knockout T Cells Demonstrate Defective Receptor Trafficking, Proliferation, and Effector Function. Mol. Cell. Biol. 2013, 33, 958-973. [CrossRef]

21. Steinberg, F.; Heesom, K.J.; Bass, M.D.; Cullen, P.J. SNX17 protects integrins from degradation by sorting between lysosomal and recycling pathways. J. Cell Biol. 2012, 197, 219-230. [CrossRef] 
22. Kvainickas, A.; Jimenez-Orgaz, A.; Nägele, H.; Hu, Z.; Dengjel, J.; Steinberg, F. Cargo-selective SNX-BAR proteins mediate retromer trimer independent retrograde transport. J. Cell Biol. 2017, 216, 3677-3693. [CrossRef] [PubMed]

23. McNally, K.E.; Faulkner, R.; Steinberg, F.; Gallon, M.; Ghai, R.; Pim, D.; Langton, P.; Pearson, N.; Danson, C.M.; Nägele, H.; et al. Retriever is a multiprotein complex for retromer-independent endosomal cargo recycling. Nat. Cell Biol. 2017, 19, 1214-1225. [CrossRef] [PubMed]

24. Phillips-Krawczak, C.A.; Singla, A.; Starokadomskyy, P.; Deng, Z.; Osborne, D.G.; Li, H.; Dick, C.J.; Gomez, T.S.; Koenecke, M.; Zhang, J.-S.; et al. COMMD1 is linked to the WASH complex and regulates endosomal trafficking of the copper transporter ATP7A. Mol. Biol. Cell 2015, 26, 91-103. [CrossRef] [PubMed]

25. Osborne, D.G.; Piotrowski, J.T.; Dick, C.J.; Zhang, J.-S.; Billadeau, D.D. SNX17 Affects T Cell Activation by Regulating TCR and Integrin Recycling. J. Immunol. 2015, 194, 4555-4566. [CrossRef] [PubMed]

26. Raiborg, C.; Stenmark, H. The ESCRT machinery in endosomal sorting of ubiquitylated membrane proteins. Nature 2009, 458, 445-452. [CrossRef] [PubMed]

27. McNally, K.E.; Cullen, P.J. Endosomal Retrieval of Cargo: Retromer Is Not Alone. Trends Cell Biol. 2018, 28, 807-822. [CrossRef]

28. Vicinanza, M.; D'Angelo, G.; Di Campli, A.; De Matteis, M.A. Function and dysfunction of the PI system in membrane trafficking. EMBO J. 2008, 27, 2457-2470. [CrossRef]

29. Anitei, M.; Hoflack, B. Bridging membrane and cytoskeleton dynamics in the secretory and endocytic pathways. Nat. Cell Biol. 2012, 14, 11-19. [CrossRef]

30. Zerial, M.; McBride, H. Rab proteins as membrane organizers. Nat. Rev. Mol. Cell Biol. 2001, 2, $107-117$. [CrossRef]

31. Di Paolo, G.; De Camilli, P. Phosphoinositides in cell regulation and membrane dynamics. Nature 2006, 443, 651-657. [CrossRef]

32. Matteis, M.A.D.; Godi, A. PI-loting membrane traffic. Nat. Cell Biol. 2004, 6, 487-492. [CrossRef] [PubMed]

33. Hong, W. SNAREs and traffic. Biochim. Biophys. Acta BBA Mol. Cell Res. 2005, 1744, 120-144. [CrossRef] [PubMed]

34. Jahn, R.; Scheller, R.H. SNAREs-Engines for membrane fusion. Nat. Rev. Mol. Cell Biol. 2006, 7, 631-643. [CrossRef] [PubMed]

35. Almena, M.; Mérida, I. Shaping up the membrane: Diacylglycerol coordinates spatial orientation of signaling. Trends Biochem. Sci. 2011, 36, 593-603. [CrossRef]

36. Rhee, S.G.; Bae, Y.S. Regulation of Phosphoinositide-specific Phospholipase C Isozymes. J. Biol. Chem. 1997, 272, 15045-15048. [CrossRef]

37. Hogan, P.G. Transcriptional regulation by calcium, calcineurin, and NFAT. Genes Dev. 2003, 17, $2205-2232$. [CrossRef]

38. Gwack, Y.; Feske, S.; Srikanth, S.; Hogan, P.G.; Rao, A. Signalling to transcription: Store-operated Ca ${ }^{2+}$ entry $^{+}$ and NFAT activation in lymphocytes. Cell Calcium 2007, 42, 145-156. [CrossRef] [PubMed]

39. Ebinu, J.O. RasGRP, a Ras Guanyl Nucleotide- Releasing Protein with Calcium- and Diacylglycerol-Binding Motifs. Science 1998, 280, 1082-1086. [CrossRef] [PubMed]

40. Ebinu, J.O.; Stang, S.L.; Teixeira, C.; Bottorff, D.A.; Hooton, J.; Blumberg, P.M.; Barry, M.; Bleakley, R.C.; Ostergaard, H.L.; Stone, J.C. RasGRP links T-cell receptor signaling to Ras. Blood 2000, 95, 3199-3203. [CrossRef]

41. Roose, J.P.; Mollenauer, M.; Gupta, V.A.; Stone, J.; Weiss, A. A Diacylglycerol-Protein Kinase C-RasGRP1 Pathway Directs Ras Activation upon Antigen Receptor Stimulation of T Cells. Mol. Cell. Biol. 2005, 25, 4426-4441. [CrossRef]

42. Gharbi, S.I.; Avila-Flores, A.; Soutar, D.; Orive, A.; Koretzky, G.A.; Albar, J.P.; Merida, I. Transient PKC shuttling to the immunological synapse is governed by DGK and regulates L-selectin shedding. J. Cell Sci. 2013, 126, 2176-2186. [CrossRef] [PubMed]

43. Lin, X.; O'Mahony, A.; Mu, Y.; Geleziunas, R.; Greene, W.C. Protein kinase C-theta participates in NF-kappaB activation induced by CD3-CD28 costimulation through selective activation of IkappaB kinase beta. Mol. Cell. Biol. 2000, 20, 2933-2940. [CrossRef] [PubMed]

44. Gorentla, B.K.; Wan, C.-K.; Zhong, X.-P. Negative regulation of mTOR activation by diacylglycerol kinases. Blood 2011, 117, 4022-4031. [CrossRef] [PubMed] 
45. Shulga, Y.V.; Topham, M.K.; Epand, R.M. Regulation and Functions of Diacylglycerol Kinases. Chem. Rev. 2011, 111, 6186-6208. [CrossRef]

46. Mérida, I.; Andrada, E.; Gharbi, S.I.; Ávila-Flores, A. Redundant and specialized roles for diacylglycerol kinases $\alpha$ and $\zeta$ in the control of T cell functions. Sci. Signal. 2015, 8, re6. [CrossRef]

47. Quann, E.J.; Merino, E.; Furuta, T.; Huse, M. Localized diacylglycerol drives the polarization of the microtubule-organizing center in T cells. Nat. Immunol. 2009, 10, 627-635. [CrossRef]

48. Quann, E.J.; Liu, X.; Altan-Bonnet, G.; Huse, M. A cascade of protein kinase C isozymes promotes cytoskeletal polarization in T cells. Nat. Immunol. 2011, 12, 647-654. [CrossRef]

49. Liu, X.; Kapoor, T.M.; Chen, J.K.; Huse, M. Diacylglycerol promotes centrosome polarization in T cells via reciprocal localization of dynein and myosin II. Proc. Natl. Acad. Sci. USA 2013, 110, 11976-11981. [CrossRef]

50. Combs, J.; Kim, S.J.; Tan, S.; Ligon, L.A.; Holzbaur, E.L.F.; Kuhn, J.; Poenie, M. Recruitment of dynein to the Jurkat immunological synapse. Proc. Natl. Acad. Sci. USA 2006, 103, 14883-14888. [CrossRef]

51. Hashimoto-Tane, A.; Yokosuka, T.; Sakata-Sogawa, K.; Sakuma, M.; Ishihara, C.; Tokunaga, M.; Saito, T. Dynein-Driven Transport of T Cell Receptor Microclusters Regulates Immune Synapse Formation and T Cell Activation. Immunity 2011, 34, 919-931. [CrossRef]

52. Martín-Cófreces, N.B.; Robles-Valero, J.; Cabrero, J.R.; Mittelbrunn, M.; Gordón-Alonso, M.; Sung, C.-H.; Alarcón, B.; Vázquez, J.; Sánchez-Madrid, F. MTOC translocation modulates IS formation and controls sustained T cell signaling. J. Cell Biol. 2008, 182, 951-962. [CrossRef] [PubMed]

53. Spitaler, M.; Emslie, E.; Wood, C.D.; Cantrell, D. Diacylglycerol and Protein Kinase D Localization during T Lymphocyte Activation. Immunity 2006, 24, 535-546. [CrossRef] [PubMed]

54. Medeiros, R.B.; Dickey, D.M.; Chung, H.; Quale, A.C.; Nagarajan, L.R.; Billadeau, D.D.; Shimizu, Y. Protein kinase D1 and the beta 1 integrin cytoplasmic domain control beta 1 integrin function via regulation of Rap1 activation. Immunity 2005, 23, 213-226. [CrossRef] [PubMed]

55. Wang, Q.J. PKD at the crossroads of DAG and PKC signaling. Trends Pharmacol. Sci. 2006, 27, 317-323. [CrossRef]

56. Mazzeo, C.; Calvo, V.; Alonso, R.; Mérida, I.; Izquierdo, M. Protein kinase D1/2 is involved in the maturation of multivesicular bodies and secretion of exosomes in T and B lymphocytes. Cell Death Differ. 2016, 23, 99-109. [CrossRef] [PubMed]

57. Wang, S.; Li, Y.; Gong, J.; Ye, S.; Yang, X.; Zhang, R.; Ma, C. Munc18 and Munc13 serve as a functional template to orchestrate neuronal SNARE complex assembly. Nat. Commun. 2019, 10, 1-14. [CrossRef]

58. Betz, A.; Ashery, U.; Rickmann, M.; Augustin, I.; Neher, E.; Südhof, T.C.; Rettig, J.; Brose, N. Munc13-1 Is a Presynaptic Phorbol Ester Receptor that Enhances Neurotransmitter Release. Neuron 1998, 21, 123-136. [CrossRef]

59. Augustin, I.; Rosenmund, C.; Südhof, T.C.; Brose, N. Munc13-1 is essential for fusion competence of glutamatergic synaptic vesicles. Nature 1999, 400, 457-461. [CrossRef]

60. Rhee, J.-S.; Betz, A.; Pyott, S.; Reim, K.; Varoqueaux, F.; Augustin, I.; Hesse, D.; Südhof, T.C.; Takahashi, M.; Rosenmund, C.; et al. $\beta$ Phorbol Ester- and Diacylglycerol-Induced Augmentation of Transmitter Release Is Mediated by Munc13s and Not by PKCs. Cell 2002, 108, 121-133. [CrossRef]

61. Feldmann, J.; Callebaut, I.; Raposo, G.; Certain, S.; Bacq, D.; Dumont, C.; Lambert, N.; Ouachée-Chardin, M.; Chedeville, G.; Tamary, H.; et al. Munc13-4 Is Essential for Cytolytic Granules Fusion and Is Mutated in a Form of Familial Hemophagocytic Lymphohistiocytosis (FHL3). Cell 2003, 115, 461-473. [CrossRef]

62. Neeft, M.; Wieffer, M.; de Jong, A.S.; Negroiu, G.; Metz, C.H.G.; van Loon, A.; Griffith, J.; Krijgsveld, J.; Wulffraat, N.; Koch, H.; et al. Munc13-4 Is an Effector of Rab27a and Controls Secretion of Lysosomes in Hematopoietic Cells. Mol. Biol. Cell 2005, 16, 731-741. [CrossRef] [PubMed]

63. Dudenhöffer-Pfeifer, M.; Schirra, C.; Pattu, V.; Halimani, M.; Maier-Peuschel, M.; Marshall, M.R.; Matti, U.; Becherer, U.; Dirks, J.; Jung, M.; et al. Different Munc13 Isoforms Function as Priming Factors in Lytic Granule Release from Murine Cytotoxic T Lymphocytes: Munc13 Isoforms in Cytotoxic T Lymphocytes. Traffic 2013, 14, 798-809. [CrossRef] [PubMed]

64. Côte, M.; Ménager, M.M.; Burgess, A.; Mahlaoui, N.; Picard, C.; Schaffner, C.; Al-Manjomi, F.; Al-Harbi, M.; Alangari, A.; Le Deist, F.; et al. Munc18-2 deficiency causes familial hemophagocytic lymphohistiocytosis type 5 and impairs cytotoxic granule exocytosis in patient NK cells. J. Clin. Investig. 2009, 119, 3765-3773. [CrossRef] [PubMed] 
65. Barclay, J.W.; Craig, T.J.; Fisher, R.J.; Ciufo, L.F.; Evans, G.J.O.; Morgan, A.; Burgoyne, R.D. Phosphorylation of Munc18 by Protein Kinase C Regulates the Kinetics of Exocytosis. J. Biol. Chem. 2003, 278, 10538-10545. [CrossRef] [PubMed]

66. Jenkins, G.H.; Fisette, P.L.; Anderson, R.A. Type I phosphatidylinositol 4-phosphate 5-kinase isoforms are specifically stimulated by phosphatidic acid. J. Biol. Chem. 1994, 269, 11547-11554.

67. Cockcroft, S. Phosphatidic acid regulation of phosphatidylinositol 4-phosphate 5-kinases. Biochim. Biophys. Acta BBA-Mol. Cell Biol. Lipids 2009, 1791, 905-912. [CrossRef] [PubMed]

68. Roach, A.N.; Wang, Z.; Wu, P.; Zhang, F.; Chan, R.B.; Yonekubo, Y.; Di Paolo, G.; Gorfe, A.A.; Du, G. Phosphatidic acid regulation of PIPKI is critical for actin cytoskeletal reorganization. J. Lipid Res. 2012, 53, 2598-2609. [CrossRef] [PubMed]

69. Gawden-Bone, C.M.; Frazer, G.L.; Richard, A.C.; Ma, C.Y.; Strege, K.; Griffiths, G.M. PIP5 Kinases Regulate Membrane Phosphoinositide and Actin Composition for Targeted Granule Secretion by Cytotoxic Lymphocytes. Immunity 2018, 49, 427-437.e4. [CrossRef] [PubMed]

70. Holden, N.J.; Savage, C.O.S.; Young, S.P.; Wakelam, M.J.; Harper, L.; Williams, J.M. A Dual Role for Diacylglycerol Kinase Generated Phosphatidic Acid in Autoantibody-Induced Neutrophil Exocytosis. Mol. Med. 2011, 17, 1242-1252. [CrossRef]

71. Humeau, Y.; Vitale, N.; Chasserot-Golaz, S.; Dupont, J.-L.; Du, G.; Frohman, M.A.; Bader, M.-F.; Poulain, B. A role for phospholipase D1 in neurotransmitter release. Proc. Natl. Acad. Sci. USA 2001, 98, 15300-15305. [CrossRef]

72. Carrasco, S.; Mérida, I. Diacylglycerol, when simplicity becomes complex. Trends Biochem. Sci. 2007, 32, 27-36. [CrossRef] [PubMed]

73. Lam, A.D.; Tryoen-Toth, P.; Tsai, B.; Vitale, N.; Stuenkel, E.L. SNARE-catalyzed Fusion Events Are Regulated by Syntaxin1A-Lipid Interactions. Mol. Biol. Cell 2008, 19, 485-497. [CrossRef] [PubMed]

74. Starr, M.L.; Hurst, L.R.; Fratti, R.A. Phosphatidic Acid Sequesters Sec18p from cis-SNARE Complexes to Inhibit Priming. Traffic Cph. Den. 2016, 17, 1091-1109. [CrossRef] [PubMed]

75. Mérida, I.; Ávila-Flores, A.; Merino, E. Diacylglycerol kinases: At the hub of cell signalling. Biochem. J. 2008, 409, 1-18. [CrossRef] [PubMed]

76. Gharbi, S.I.; Rincón, E.; Avila-Flores, A.; Torres-Ayuso, P.; Almena, M.; Cobos, M.A.; Albar, J.P.; Mérida, I. Diacylglycerol kinase $\zeta$ controls diacylglycerol metabolism at the immunological synapse. Mol. Biol. Cell 2011, 22, 4406-4414. [CrossRef] [PubMed]

77. Chauveau, A.; Le Floc'h, A.; Bantilan, N.S.; Koretzky, G.A.; Huse, M. Diacylglycerol kinase $\alpha$ establishes T cell polarity by shaping diacylglycerol accumulation at the immunological synapse. Sci. Signal. 2014, 7, ra82. [CrossRef]

78. Ávila-Flores, A.; Arranz-Nicolás, J.; Andrada, E.; Soutar, D.; Mérida, I. Predominant contribution of DGK乙 over DGK $\alpha$ in the control of PKC/PDK-1-regulated functions in T cells. Immunol. Cell Biol. 2017, 95, 549-563. [CrossRef]

79. Topham, M.K.; Prescott, S.M. Diacylglycerol kinase zeta regulates Ras activation by a novel mechanism. J. Cell Biol. 2001, 152, 1135-1143. [CrossRef]

80. Zhong, X.-P.; Hainey, E.A.; Olenchock, B.A.; Zhao, H.; Topham, M.K.; Koretzky, G.A. Regulation of T Cell Receptor-induced Activation of the Ras-ERK Pathway by Diacylglycerol Kinase ל. J. Biol. Chem. 2002, 277, 31089-31098. [CrossRef]

81. Joshi, R.P.; Schmidt, A.M.; Das, J.; Pytel, D.; Riese, M.J.; Lester, M.; Diehl, J.A.; Behrens, E.M.; Kambayashi, T.; Koretzky, G.A. The $\zeta$ isoform of diacylglycerol kinase plays a predominant role in regulatory $\mathrm{T}$ cell development and TCR-mediated ras signaling. Sci. Signal. 2013, 6, ra102. [CrossRef]

82. Andrada, E.; Liébana, R.; Merida, I. Diacylglycerol Kinase $\zeta$ Limits Cytokine-dependent Expansion of CD8+ T Cells with Broad Antitumor Capacity. EBioMedicine 2017, 19, 39-48. [CrossRef] [PubMed]

83. Riese, M.J.; Grewal, J.; Das, J.; Zou, T.; Patil, V.; Chakraborty, A.K.; Koretzky, G.A. Decreased diacylglycerol metabolism enhances ERK activation and augments CD8+ T cell functional responses. J. Biol. Chem. 2011, 286, 5254-5265. [CrossRef] [PubMed]

84. Riese, M.J.; Wang, L.-C.S.; Moon, E.K.; Joshi, R.P.; Ranganathan, A.; June, C.H.; Koretzky, G.A.; Albelda, S.M. Enhanced effector responses in activated CD8+ T cells deficient in diacylglycerol kinases. Cancer Res. 2013, 73, 3566-3577. [CrossRef] [PubMed] 
85. Andrada, E.; Almena, M.; de Guinoa, J.S.; Merino-Cortes, S.V.; Liébana, R.; Arcos, R.; Carrasco, S.; Carrasco, Y.R.; Merida, I. Diacylglycerol kinase $\zeta$ limits the polarized recruitment of diacylglycerol-enriched organelles to the immune synapse in T cells. Sci. Signal. 2016, 9, ra127. [CrossRef] [PubMed]

86. Chianale, F.; Rainero, E.; Cianflone, C.; Bettio, V.; Pighini, A.; Porporato, P.E.; Filigheddu, N.; Serini, G.; Sinigaglia, F.; Baldanzi, G.; et al. Diacylglycerol kinase alpha mediates HGF-induced Rac activation and membrane ruffling by regulating atypical PKC and RhoGDI. Proc. Natl. Acad. Sci. USA 2010, 107, 4182-4187. [CrossRef]

87. Bertrand, F.; Esquerré, M.; Petit, A.-E.; Rodrigues, M.; Duchez, S.; Delon, J.; Valitutti, S. Activation of the Ancestral Polarity Regulator Protein Kinase C $\zeta$ at the Immunological Synapse Drives Polarization of Th Cell Secretory Machinery toward APCs. J. Immunol. 2010, 185, 2887-2894. [CrossRef]

88. Bertrand, F.; Müller, S.; Roh, K.-H.; Laurent, C.; Dupré, L.; Valitutti, S. An initial and rapid step of lytic granule secretion precedes microtubule organizing center polarization at the cytotoxic T lymphocyte/target cell synapse. Proc. Natl. Acad. Sci. USA 2013, 110, 6073-6078. [CrossRef]

89. Merino-Cortés, S.V.; Gardeta, S.R.; Roman-Garcia, S.; Martínez-Riaño, A.; Pineau, J.; Liebana, R.; Merida, I.; Dumenil, A.-M.L.; Pierobon, P.; Husson, J.; et al. Diacylglycerol kinase $\zeta$ promotes actin cytoskeleton remodeling and mechanical forces at the B cell immune synapse. Sci. Signal. 2020, 13. [CrossRef]

90. Carlton, J.; Bujny, M.; Rutherford, A.; Cullen, P. Sorting Nexins-Unifying Trends and New Perspectives: The Role of Sorting Nexins in Endosomal Sorting. Traffic 2005, 6, 75-82. [CrossRef]

91. Cullen, P.J.; Korswagen, H.C. Sorting nexins provide diversity for retromer-dependent trafficking events. Nat. Cell Biol. 2012, 14, 29-37. [CrossRef]

92. Ghai, R.; Mobli, M.; Norwood, S.J.; Bugarcic, A.; Teasdale, R.D.; King, G.F.; Collins, B.M. Phox homology band 4.1/ezrin/radixin/moesin-like proteins function as molecular scaffolds that interact with cargo receptors and Ras GTPases. Proc. Natl. Acad. Sci. USA 2011, 108, 7763-7768. [CrossRef] [PubMed]

93. Teasdale, R.D.; Collins, B.M. Insights into the PX (phox-homology) domain and SNX (sorting nexin) protein families: Structures, functions and roles in disease. Biochem. J. 2012, 441, 39-59. [CrossRef] [PubMed]

94. Ghai, R.; Bugarcic, A.; Liu, H.; Norwood, S.J.; Skeldal, S.; Coulson, E.J.; Li, S.S.-C.; Teasdale, R.D.; Collins, B.M. Structural basis for endosomal trafficking of diverse transmembrane cargos by PX-FERM proteins. Proc. Natl. Acad. Sci. USA 2013, 110, E643-E652. [CrossRef] [PubMed]

95. Loo, L.S.; Tang, N.; Al-Haddawi, M.; Stewart Dawe, G.; Hong, W. A role for sorting nexin 27 in AMPA receptor trafficking. Nat. Commun. 2014, 5, 3176. [CrossRef]

96. Böttcher, R.T.; Stremmel, C.; Meves, A.; Meyer, H.; Widmaier, M.; Tseng, H.-Y.; Fässler, R. Sorting nexin 17 prevents lysosomal degradation of $\beta 1$ integrins by binding to the $\beta 1$-integrin tail. Nat. Cell Biol. 2012, 14, 584-592. [CrossRef]

97. van Kerkhof, P.; Lee, J.; McCormick, L.; Tetrault, E.; Lu, W.; Schoenfish, M.; Oorschot, V.; Strous, G.J.; Klumperman, J.; Bu, G. Sorting nexin 17 facilitates LRP recycling in the early endosome. EMBO J. 2005, 24, 2851-2861. [CrossRef] [PubMed]

98. Burden, J.J.; Sun, X.-M.; García, A.B.G.; Soutar, A.K. Sorting Motifs in the Intracellular Domain of the Low Density Lipoprotein Receptor Interact with a Novel Domain of Sorting Nexin-17. J. Biol. Chem. 2004, 279, 16237-16245. [CrossRef] [PubMed]

99. Knauth, P.; Schlüter, T.; Czubayko, M.; Kirsch, C.; Florian, V.; Schreckenberger, S.; Hahn, H.; Bohnensack, R. Functions of Sorting Nexin 17 Domains and Recognition Motif for P-selectin Trafficking. J. Mol. Biol. 2005, 347, 813-825. [CrossRef]

100. Tseng, H.-Y.; Thorausch, N.; Ziegler, T.; Meves, A.; Fässler, R.; Böttcher, R.T. Sorting nexin 31 binds multiple $\beta$ integrin cytoplasmic domains and regulates $\beta 1$ integrin surface levels and stability. J. Mol. Biol. 2014, 426, 3180-3194. [CrossRef]

101. Peter, B.J. BAR Domains as Sensors of Membrane Curvature: The Amphiphysin BAR Structure. Science 2004, 303, 495-499. [CrossRef]

102. Pylypenko, O.; Lundmark, R.; Rasmuson, E.; Carlsson, S.R.; Rak, A. The PX-BAR membrane-remodeling unit of sorting nexin 9. EMBO J. 2007, 26, 4788-4800. [CrossRef] [PubMed]

103. Carlton, J.; Bujny, M.; Peter, B.J.; Oorschot, V.M.J.; Rutherford, A.; Mellor, H.; Klumperman, J.; McMahon, H.T.; Cullen, P.J. Sorting Nexin-1 Mediates Tubular Endosome-to-TGN Transport through Coincidence Sensing of High- Curvature Membranes and 3-Phosphoinositides. Curr. Biol. 2004, 14, 1791-1800. [CrossRef] [PubMed]

104. Seaman, M. Recycle your receptors with retromer. Trends Cell Biol. 2005, 15, 68-75. [CrossRef] [PubMed] 
105. Bonifacino, J.S.; Hurley, J.H. Retromer. Curr. Opin. Cell Biol. 2008, 20, 427-436. [CrossRef] [PubMed]

106. Attar, N.; Cullen, P.J. The retromer complex. Adv. Enzyme Regul. 2010, 50, 216-236. [CrossRef]

107. Haft, C.R.; de la Luz Sierra, M.; Bafford, R.; Lesniak, M.A.; Barr, V.A.; Taylor, S.I. Human Orthologs of Yeast Vacuolar Protein Sorting Proteins Vps26, 29, and 35: Assembly into Multimeric Complexes. Mol. Biol. Cell 2000, 11, 4105-4116. [CrossRef] [PubMed]

108. Hierro, A.; Rojas, A.L.; Rojas, R.; Murthy, N.; Effantin, G.; Kajava, A.V.; Steven, A.C.; Bonifacino, J.S.; Hurley, J.H. Functional architecture of the retromer cargo-recognition complex. Nature 2007, 449, 1063-1067. [CrossRef] [PubMed]

109. Kerr, M.C.; Bennetts, J.S.; Simpson, F.; Thomas, E.C.; Flegg, C.; Gleeson, P.A.; Wicking, C.; Teasdale, R.D. A Novel Mammalian Retromer Component, Vps26B: Novel Retromer Protein, Vps26B. Traffic 2005, 6, 991-1001. [CrossRef]

110. Seaman, M.N.J. The retromer complex - endosomal protein recycling and beyond. J. Cell Sci. 2012, 125, 4693-4702. [CrossRef] [PubMed]

111. Gallon, M.; Cullen, P.J. Retromer and sorting nexins in endosomal sorting. Biochem. Soc. Trans. 2015, 43, 33-47. [CrossRef] [PubMed]

112. Burd, C.; Cullen, P.J. Retromer: A Master Conductor of Endosome Sorting. Cold Spring Harb. Perspect. Biol. 2014, 6, a016774. [CrossRef] [PubMed]

113. Wassmer, T.; Attar, N.; Harterink, M.; van Weering, J.R.T.; Traer, C.J.; Oakley, J.; Goud, B.; Stephens, D.J.; Verkade, P.; Korswagen, H.C.; et al. The Retromer Coat Complex Coordinates Endosomal Sorting and Dynein-Mediated Transport, with Carrier Recognition by the trans-Golgi Network. Dev. Cell 2009, 17, 110-122. [CrossRef] [PubMed]

114. Steinberg, F.; Gallon, M.; Winfield, M.; Thomas, E.C.; Bell, A.J.; Heesom, K.J.; Tavaré, J.M.; Cullen, P.J. A global analysis of SNX27-retromer assembly and cargo specificity reveals a function in glucose and metal ion transport. Nat. Cell Biol. 2013, 15, 461-471. [CrossRef] [PubMed]

115. Temkin, P.; Lauffer, B.; Jäger, S.; Cimermancic, P.; Krogan, N.J.; von Zastrow, M. SNX27 mediates retromer tubule entry and endosome-to-plasma membrane trafficking of signalling receptors. Nat. Cell Biol. 2011, 13, 715-721. [CrossRef] [PubMed]

116. Gallon, M.; Clairfeuille, T.; Steinberg, F.; Mas, C.; Ghai, R.; Sessions, R.B.; Teasdale, R.D.; Collins, B.M.; Cullen, P.J. A unique PDZ domain and arrestin-like fold interaction reveals mechanistic details of endocytic recycling by SNX27-retromer. Proc. Natl. Acad. Sci. USA 2014, 111, E3604-E3613. [CrossRef] [PubMed]

117. Ghai, R.; Tello-Lafoz, M.; Norwood, S.J.; Yang, Z.; Clairfeuille, T.; Teasdale, R.D.; Merida, I.; Collins, B.M. Phosphoinositide binding by the SNX27 FERM domain regulates its localization at the immune synapse of activated T-cells. J. Cell Sci. 2015, 128, 553-565. [CrossRef]

118. Gomez, T.S.; Billadeau, D.D. A FAM21-Containing WASH Complex Regulates Retromer-Dependent Sorting. Dev. Cell 2009, 17, 699-711. [CrossRef]

119. Gomez, T.S.; Gorman, J.A.; de Narvajas, A.A.-M.; Koenig, A.O.; Billadeau, D.D. Trafficking defects in WASH-knockout fibroblasts originate from collapsed endosomal and lysosomal networks. Mol. Biol. Cell 2012, 23, 3215-3228. [CrossRef]

120. Harbour, M.E.; Breusegem, S.Y.; Seaman, M.N.J. Recruitment of the endosomal WASH complex is mediated by the extended 'tail' of Fam21 binding to the retromer protein Vps35. Biochem. J. 2012, 442, 209-220. [CrossRef]

121. Jia, D.; Gomez, T.S.; Billadeau, D.D.; Rosen, M.K. Multiple repeat elements within the FAM21 tail link the WASH actin regulatory complex to the retromer. Mol. Biol. Cell 2012, 23, 2352-2361. [CrossRef]

122. Lauffer, B.E.L.; Melero, C.; Temkin, P.; Lei, C.; Hong, W.; Kortemme, T.; von Zastrow, M. SNX27 mediates PDZ-directed sorting from endosomes to the plasma membrane. J. Cell Biol. 2010, 190, 565-574. [CrossRef] [PubMed]

123. Lunn, M.-L.; Nassirpour, R.; Arrabit, C.; Tan, J.; Mcleod, I.; Arias, C.M.; Sawchenko, P.E.; Yates, J.R.; Slesinger, P.A. A unique sorting nexin regulates trafficking of potassium channels via a PDZ domain interaction. Nat. Neurosci. 2007, 10, 1249-1259. [CrossRef] [PubMed]

124. Yang, Z.; Follett, J.; Kerr, M.C.; Clairfeuille, T.; Chandra, M.; Collins, B.M.; Teasdale, R.D. Sorting nexin 27 (SNX27) regulates the trafficking and activity of the glutamine transporter ASCT2. J. Biol. Chem. 2018, 293, 6802-6811. [CrossRef] [PubMed] 
125. Rincón, E.; Santos, T.; Avila-Flores, A.; Albar, J.P.; Lalioti, V.; Lei, C.; Hong, W.; Mérida, I. Proteomics identification of sorting nexin 27 as a diacylglycerol kinase zeta-associated protein: New diacylglycerol kinase roles in endocytic recycling. Mol. Cell. Proteom. MCP 2007, 6, 1073-1087. [CrossRef] [PubMed]

126. Rincon, E.; de Guinoa, J.S.; Gharbi, S.I.; Sorzano, C.O.S.; Carrasco, Y.R.; Merida, I. Translocation dynamics of sorting nexin 27 in activated T cells. J. Cell Sci. 2011, 124, 776-788. [CrossRef] [PubMed]

127. Tello-Lafoz, M.; Martínez-Martínez, G.; Rodríguez-Rodríguez, C.; Albar, J.P.; Huse, M.; Gharbi, S.; Merida, I. Sorting nexin 27 interactome in T-lymphocytes identifies zona occludens-2 dynamic redistribution at the immune synapse. Traffic 2017, 18, 491-504. [CrossRef]

128. MacNeil, A.J.; Mansour, M.; Pohajdak, B. Sorting nexin 27 interacts with the Cytohesin associated scaffolding protein (CASP) in lymphocytes. Biochem. Biophys. Res. Commun. 2007, 359, 848-853. [CrossRef]

129. Deswal, S.; Meyer, A.; Fiala, G.J.; Eisenhardt, A.E.; Schmitt, L.C.; Salek, M.; Brummer, T.; Acuto, O.; Schamel, W.W.A. Kidins220/ARMS Associates with B-Raf and the TCR, Promoting Sustained Erk Signaling in T Cells. J. Immunol. 2013, 190, 1927-1935. [CrossRef]

130. Becherer, U.; Medart, M.R.; Schirra, C.; Krause, E.; Stevens, D.; Rettig, J. Regulated exocytosis in chromaffin cells and cytotoxic T lymphocytes: How similar are they? Cell Calcium 2012, 52, 303-312. [CrossRef]

131. Wang, X.; Zhao, Y.; Zhang, X.; Badie, H.; Zhou, Y.; Mu, Y.; Loo, L.S.; Cai, L.; Thompson, R.C.; Yang, B.; et al. Loss of sorting nexin 27 contributes to excitatory synaptic dysfunction via modulation of glutamate receptor recycling in Down syndrome. Nat. Med. 2013, 19, 473-480. [CrossRef]

132. Wang, X.; Huang, T.; Zhao, Y.; Zheng, Q.; Thompson, R.C.; Bu, G.; Zhang, Y.; Hong, W.; Xu, H. Sorting nexin 27 regulates $A \beta$ production through modulating $\gamma$-secretase activity. Cell Rep. 2014, 9, 1023-1033. [CrossRef] [PubMed]

133. Zhang, J.; Li, K.; Zhang, Y.; Lu, R.; Wu, S.; Tang, J.; Xia, Y.; Sun, J. Deletion of sorting nexin 27 suppresses proliferation in highly aggressive breast cancer MDA-MB-231 cells in vitro and in vivo. BMC Cancer 2019, 19, 555. [CrossRef] [PubMed]

134. Sharma, P.; Parveen, S.; Shah, L.V.; Mukherjee, M.; Kalaidzidis, Y.; Kozielski, A.J.; Rosato, R.; Chang, J.C.; Datta, S. SNX27-retromer assembly recycles MT1-MMP to invadopodia and promotes breast cancer metastasis. J. Cell Biol. 2020, 219, e201812098. [CrossRef]

135. Clairfeuille, T.; Mas, C.; Chan, A.S.M.; Yang, Z.; Tello-Lafoz, M.; Chandra, M.; Widagdo, J.; Kerr, M.C.; Paul, B.; Mérida, I.; et al. A molecular code for endosomal recycling of phosphorylated cargos by the SNX27-retromer complex. Nat. Struct. Mol. Biol. 2016, 23, 921-932. [CrossRef] [PubMed]

136. Tello-Lafoz, M.; Rodríguez-Rodríguez, C.; Kinna, G.; Loo, L.S.; Hong, W.; Collins, B.M.; Teasdale, R.D.; Mérida, I. SNX27 links DGKC to the control of transcriptional and metabolic programs in T lymphocytes. Sci. Rep. 2017, 7, 16361. [CrossRef] [PubMed]

137. Krummel, M.F.; Macara, I. Maintenance and modulation of T cell polarity. Nat. Immunol. 2006, 7, 1143-1149. [CrossRef] [PubMed]

138. Lasiecka, Z.M.; Winckler, B. Mechanisms of polarized membrane trafficking in neurons-Focusing in on endosomes. Mol. Cell. Neurosci. 2011, 48, 278-287. [CrossRef]

139. Sann, S.; Wang, Z.; Brown, H.; Jin, Y. Roles of endosomal trafficking in neurite outgrowth and guidance. Trends Cell Biol. 2009, 19, 317-324. [CrossRef]

140. Benvenuti, F. The Dendritic Cell Synapse: A Life Dedicated to T Cell Activation. Front. Immunol. 2016, 7, 70. [CrossRef]

141. Verboogen, D.R.J.; Dingjan, I.; Revelo, N.H.; Visser, L.J.; ter Beest, M.; van den Bogaart, G. The dendritic cell side of the immunological synapse. Biomol. Concepts 2016, 7, 17-28. [CrossRef]

(C) 2020 by the authors. Licensee MDPI, Basel, Switzerland. This article is an open access article distributed under the terms and conditions of the Creative Commons Attribution (CC BY) license (http://creativecommons.org/licenses/by/4.0/). 